DOI: $10.2478 / \mathrm{v} 10025-009-0003-\mathrm{Z}$

\title{
Irrigation system control under uncertainty conditions
}

\author{
Peter KOVALENKO, Yuri MIKHAYLOV
}

Institute of Hydraulic Engineering and Land Reclamation Ukraine, 03022, Kyiv 22, 37, Vasylkivska str.; phone: +380-442-574-030, fax: +380-442-574-001, e-mail: igim@creator.ukrsat.com, kovalen@ user.ukrsat.com

\begin{abstract}
The irrigation system control is identified as a complex hierarchical process of stochastic nature, at the head of which the uncertainties, caused by random variations of meteorological factors (climate) and diversion capacity regime from irrigation canals, were laid.

Under such conditions application of the determinate methods for irrigation system control regarding the effectiveness surrenders to the formalistic and empirical methods.

The most appropriate method is the developed by us, method of preventive control.

As a result of retrospective analysis, to each system status, for example, diversion capacity, it is fixed the factors which lead to its changes, for example, rain layer or total evaporation. To every consequence "factor - system status" it is fixed the indicator and it is determined the probability of its exceeding in retrospective series.

The control is in following of such indicator dynamics, forecasting of the most probably changes within system status and adjustment of the water delivery regime to canal reaches with diversion capacity regime from irrigation canals by means of standard preventive graphical chats of water flow control within hydraulic structures and pumping stations.

Use of such control method allows to minimize the uncertainty influence, also it does not require the major modifications in the design and engineering infrastructure.

As an exception can be the measures, directed to the increase of self-regulating qualities of irrigation systems, namely the ability of on-line water volume control, which is regulated in the idle capacities, provided in canal beds or special reservoirs.

The example of such decision in practice is the Kakhovskaya irrigation system in the South of Ukraine. The use factor of water resources on this system reaches 0.85 , the technological discharge water does not exceed $7 \%$, the deficit of productive moisture reserve in soil at the end of interirrigation period does not exceed $20 \%$ and all these data were obtained under adverse weather conditions.
\end{abstract}

Key words: irrigation, water distribution and use control

\section{INTRODUCTION}

The irrigation systems of Ukraine cover more than 2 million hectares of arable lands, mainly irrigated by sprinkling. Constructively most of irrigation systems with sprinkling represent the extensive network of open canals, where water flows 
by gravity. Diversion capacity from the canals for numerous consumes is realized by pumping stations, to which the group of water-sprinklers and sprinkling machines no less than 10 units is connected up. From the position of control theory the systems of this type are identified as the complex systems with distributed through time and space constants, which are cyclical changeable with random fluctuations.

Commonly used at present time the control methods for water distribution and use presume that these processes are deterministic, that is why fairly often there are overflows and deficit of water.

It is our belief that the proposed methodology for water distribution and use control under irrigation is deprived of many defects, can be put into effect sufficiently easily and does not require additional financial expenditure.

\section{WATER DISTRIBUTION AND USE CONTROL AS THE COMPLEX PROCESS OF STOCHASTIC NATURE}

Water distribution within irrigation systems of Ukraine is carried out by a lot of hydraulic engineering constructions and other objects. It is shown by changes of direction and velocity of water advance in canals and on fields. The interaction structure of constructions and objects is treelike. The condition of system is described by stochastic functions. As the simplified mathematical model of water distribution nonlinear implicit function can serve

$$
P_{o}+X_{n}=E_{o}+I_{o}+Y_{o}+\Delta W_{o}
$$

where:

$P_{o}+X_{n}-$ the total income of irrigation water and atmospheric precipitation to irrigation system,

$E_{o} \quad-$ total evaporation,

$I_{o} \quad-$ filtration,

$Y_{0} \quad-$ surface flow,

$\Delta W_{o} \quad-$ difference between final and initial stored soil moisture in root zone.

Independent variable is $X_{n}$, all other components (1) cooperate among themselves.

$E_{o}-X_{n}=Q_{o}-$ is the weighted average deficiency of water consumption of agricultural crops which depending on duration of the base period can be named as the irrigation rate or the irrigation depth. In view of it function (1) will become

$$
Q_{o}=P_{o}-\left(I_{o}+Y_{o}+\Delta W_{o}\right)
$$


By the nature function is stochastic, that is proved to the following. Process of formation $Q_{o}$ has the stochastic nature. By our estimations the variation of monthly values $Q_{o}$ under conditions of Ukraine lies in the range of $29-150 \%$. At the certain total atmospheric precipitation during the irrigation season, namely at $X_{n} \leq 330$ $\mathrm{mm}$, between $Q_{o}$ and $X_{n}$ the close correlation is observed ( $\left.r \geq 0.7\right)$. It allows according to known atmospheric precipitation to calculate the irrigation rate of prescribed level of supply (exceedance probability in series). Series $Q_{o}$ submit to the lognormal probability distribution law.

The stochastic nature of diversion capacity from canals is shown by randomness of its hourly vibration (perturbances) amplitude. The coefficients of variation of such perturbances series make 29-54\%, skewness - 24-94\%, autocorrelation $0.25(-0.08)$. The arithmetical average of diversion capacity perturbances increases with growth of irrigation area and autocorrelation thus decreases because of strengthening a role of random factors. Empirical probability curves of perturbances series of diversion capacity are in the best way coordinated with the lognormal probability distribution law.

Water discharge coefficient series from irrigation canals, namely

$$
\alpha_{y}=\frac{Q_{y, i}}{\bar{Q}_{y}}
$$

where

$Q_{y, i}$ - unit water discharge,

$\bar{Q}_{y} \quad$ - water discharge at canal head at the same time is characterized by significant variation $-41-87 \%$ and skewness $-37-204 \%$, autocorrelation $0.11-0.56$.

Value $\alpha_{y}$ increases with reduction of irrigation area and quantity of simultaneously working sprinkling machines.

The water discharge regime from canals has two diverse periods: 1) the beginning and the termination of sprinklings; 2) carrying out intensive sprinklings. The statistical criteria applied to discharge series, in most cases deny null hypothesis, or confirm it on the verge of admissible (a significance value $-0.10-0.20$ ), that specifies an essential role of the determined components during surface water flow formation from canals.

The uniformity of discharge series is the unusual occurrence. The homogeneous it is possible to consider the discharge series from inter-farm canals with sprinkling by sprinkling-machines of the same type. It specifies the necessity of an individual approach to water distribution control in canals of different order, the strict demonstrative approach to the analog method application. 
The stochastic nature of the basic elements of the equation (2) radically changes the methodology for control of water distribution in canals, sprinklings and water removal.

The forecast as the basis of control, will be always probabilistic, that follows from identification of water use as complex process of the stochastic nature. The main uncertainty is concluded in basic impossibility of exact forecasting quantity of atmospheric precipitation.

To weaken influence of this uncertainty, it is offered to use the typical hydrographs of diversion capacity from the canals, constructed on the basis of retrospective observational series of canal operating mode. The typical hydrographs become attached to the maximal water flow.

Prediction volume of daily diversion capacity at the water delivery point for consumer is calculated under the formula:

$$
V_{Q}=10 \sum_{i=1}^{k}\left\langle m_{H}(t)_{i} \omega_{i}\left\{\exp \left[0.4 \frac{\left(X_{n}+m_{H}(t)-3\right)^{2}}{X_{n}+m_{H}(t)}\right]\right\}\right\rangle
$$

where: $m_{H}(t)_{i}$ - net irrigation rate, $\mathrm{mm}$, for crop, occupying the part of crop rotation area $\omega_{i}$. The irrigation rate is defined by known methods.

Further under the formula $Q_{i \max }=0.0114 V_{Q}+0.1$ the maximal water flow is defined and with its help the typical daily hydrograph for given water delivery is found in the reference data.

The similar calculations are made for each pump station and every canal reach. Water delivery regime (hydrograph) into the reaches is defined by summation according to pump stations in view of transport delay time.

Hydrographs of water delivery in the canal head and also in its reaches are, as a matter of fact, the plans of water distribution.

At the water distribution planning it is necessary to consider the group work peculiarities of sprinkling machines through the empirical coefficient $k_{g r}=\bar{Q}_{i} / Q_{i \max }$. The more irrigated area, the less daily average water flow $\bar{Q}_{i}$ because of big number simultaneously working sprinkling machines results in relative stabilization of values $k_{g r}$ in the range $0,65-0,85$.

Water distribution control is preventive. Regulation of hydraulic engineering constructions and pump stations is made hourly in view of transport delay according to the prediction hydrographs of water delivery in the canal head and its reaches.

Water distribution and general use control on the irrigation system has three basic stages. 
At the beginning, leaning on (1), we make up the water balance of irrigated lands. Total evaporation is calculated by any of known methods. Filtration is defined under the formula:

$$
I_{o}=\left(1-\eta_{c}\right) P_{o}+\left[\left(1-\eta_{n}\right) f_{p}+0.26 f_{r}\right] X_{n}
$$

where:

$\eta_{c}, \eta_{n}$ - coefficients of efficiency of irrigating network and field correspondingly,

$f_{p}, f_{r} \quad-$ specific area of field and rice crop rotations correspondingly.

The total surface water flow is calculated under the formula:

$$
Y_{o}=P_{o}+X_{n}-E_{o}-I_{o}
$$

If the drainage is not present, but stored moisture in root zone has decreased, than $Y_{o}=-\Delta W_{o}$.

Water use is estimated on the relative abnormity $\Delta$ of actual values of following parameters: water delivery on the system $P_{o}$, four coefficients, describing all water use efficiency within the system $\Delta \eta_{o}$; water use efficiency of only irrigation water $-\Delta \eta_{o}{ }^{*}$; water removal $-\Delta \alpha_{o}$; productive moisture supply in root zone $-\Delta \lambda_{o}$. Calculations are carried out under formulas:

$$
\begin{gathered}
P_{o}^{*}=\frac{E_{o}^{*}-X_{n}}{\eta_{m}} \\
\Delta P_{o}=\frac{P_{o}^{*}-P_{o}}{P_{o}^{*}} 100 \% \\
\Delta \eta_{o}=100\left[1-\frac{E_{o}\left(P_{o}^{*}+X_{n}\right)}{E_{o}^{*}\left(P_{o}+X_{n}+\Delta W_{o}\right)}\right] \\
\Delta \eta_{o}^{*}=100\left[1-\frac{\left(E_{o}-X_{n}\right)\left(E_{o}^{*}-X_{n}\right)}{P_{o}^{*}\left(P_{o}-\Delta W_{o}\right)}\right] \\
\Delta \alpha_{o}=100-\Delta \eta_{o} \\
\Delta \lambda_{o}=100\left(1-\frac{\eta_{m} \eta_{n} P_{o}+X_{n}}{E_{o}}\right)
\end{gathered}
$$


where: $P_{o}{ }^{*}$ and $E_{o}{ }^{*}$ normative delivery of irrigation water to the system and total evaporation at optimum moistening of root zone correspondingly.

The deviation value, calculated under formulas (8)-(12) should not exceed \pm 10 . Otherwise it can be demanded to apply other methods for irrigation rate and irrigation depth forecasting, to check up the accuracy of water assessment, calibration of hydraulic engineering constructions and pump units, reliability of other information.

The major factor worsening the parameters of water use is excessive income of irrigation water to the systems.

One of the main conditions of qualitative water distribution and use securing on irrigation system is its assessment. The usual technological scheme of water assessment is consecutive, that is hydraulic sections and stream-gaging stations are placed on all hydraulic engineering constructions and pump stations. We offer more economical balance scheme of the water assessment, in conformity with which hydraulic sections are placed on canal and pipeline sections, which limiting group of consumers.

The total water flow on canal or pipeline section with $k$ delivery points under the balance scheme is equal to difference of water flow at the beginning and at the end of section. If delivery points by the number $k$ to group in balance sections by number $K$, the total amount of hydraulic sections will decrease in $K \sqrt{k+1}$ times. Thus the total composite accuracy of water assessment decreases, the streamgaging stations with low accuracy of water assessment easily come to light. Such water assessment scheme can be the most optimal on application of the method of channel water balance.

The most perfect control of water distribution and use does not allow to avoid water discharge completely because of the stochastic nature of these processes. This problem can be solved by creation of the idle capacities in canal beds and also the daily-storage reservoirs.

Known methods for calculation of volume control do not consider the stochastic nature of water delivery in canals and diversion capacity from them. Our method enables precisely enough to calculate control capacity (thousand $\mathrm{m}^{3}$ ) of prescribed level of supply (exceedance probability) under the formula

$$
V_{p}=4 \cdot 10^{-7} \chi_{p}\left(\Delta t_{p}\right)^{2}
$$

where

$\chi_{p} \quad$ - intensity of perturbances in diversion capacity regime from the canal of prescribed level of supply, $\mathrm{m}^{3} \cdot \mathrm{s}^{-2}$,

$\Delta t_{p}-$ duration of these perturbances, per seconds, which are calculated under formulas: 


$$
\chi_{p}=F_{z}^{2}\left(5 \cdot 10^{-4} \ln p-0.0027\right)+F_{z}(0.087-0.015 \ln p)-0.012 \ln p+0.06
$$

where: $F_{z}$ - irrigated area from the canal, thousand ha.

$$
\Delta t_{p}=0.003 F_{z}^{2}-0.64 F_{z}+38
$$

The control of diversion capacity perturbances with level of supply of 5-30\% in canal beds is economically inadvisable, because the significant canal volumes within 60-70 days of the irrigation season will not be in use.

In some cases it is expedient to accumulate water discharge from canals in special daily (and more) - storage reservoirs with use of the cumulated water for sprinkling the additional areas. The active capacity of control $V_{p}^{c c k}$ in this case is calculated under formula

$$
V_{p}^{c c k}=\frac{864 \beta Q_{k}}{F+25}
$$

where

$Q_{k}$ - water delivery in the head of the canal, $\mathrm{m}^{3} \cdot \mathrm{s}^{-1}$;

$\beta$ - reservoir storage coefficient, which is defined by means of alignment charts, cited in SVANIDZE's works [1964].

Thus the water yield of reservoir, $\mathrm{m}^{3} \cdot \mathrm{s}^{-1}$, is calculated under formula:

$$
Q_{w w}=0.04 \frac{n q_{w w} t_{w w}}{\eta_{n}}
$$

where

$n$ - quantity of sprinkling-machines with productivity $q_{w w}$,

$t_{w w}$ - irrigation period.

Economically expedient volume of reservoir available capacity for water discharge disposal from the canals is determined with assessment of variants.

Water removal beyond the bounds of irrigation systems is stochastic process. The role of deterministic component is appreciable enough. As a result of our experimental researches we have worked out the calculation method of active storage capacity for water discharge disposal.

Water removal is distributed within extensive network of collectors and wasteway canals. In such conditions it is expedient to concentrate water flow in the so-called main collectors laid on thalwegs of gullies and riverbeds of small rivers. 
If let us denote the catchment area of such collector by $F_{w z}\left(\mathrm{~km}^{2}\right)$, than the average monthly water discharge of inflow in reservoir is calculated under the formula:

$$
Y_{o}=3.7 \cdot 10^{-3} \lg \left(1.32 \frac{\Omega_{0-3}}{\Omega_{3-5}}\right) F_{w z}+0.26\left(P_{o}+X_{o}\right) \lg (i+I)
$$

where:

$\Omega_{0-3}, \Omega_{3-5}$ - area ratio in catch basin with groundwater depth of $0-3$ and 3-5 m correspondingly;

I $\quad-$ average slope of catchment (\%o) of the reservoir, numerically equal to product of both hydrographic and collector-drainage networks density $\left(\mathrm{m} \cdot \mathrm{km}^{-2}\right)$ and their average depth of incision $(\mathrm{m})$.

Not less than $80 \%$ of water removal from irrigation systems are formed during the irrigation season. Hydrographs of water removal are characterized by the certain cyclicity that it is possible to consider by means of coefficient which is defined under the formula

$$
\alpha_{o}=1-\exp \left\{A\left[\left(P_{o}+X_{n}=E_{o}\right)^{2}\left(P_{o}+X_{n}\right)^{-1}\right]+B\right.
$$

where: dimension of all parameters - thousand $\mathrm{m}^{3} \cdot \mathrm{ha}^{-1}$. Values of coefficients $A, B$ are equal: in April and October - correspondingly $(-0.7)$ and 0.10, in May - $(-0.6)$ and 0.12, in June-August $-(-0.3)$ and 0.12, in September $-(-1.4)$ and 0.13, as a whole for the season $-(-0.35)$ and 0.16 . The final active capacity of reservoir is determined with multiple assessment.

Implementation in practice of the offered method of water distribution and use control allows to save $25-30 \%$ of water resources and $10-15 \%$ of the electric power.

\section{CONCLUSIONS}

1. Water distribution and use on irrigation systems is the complex process of stochastic nature. Observational series for water balance elements of irrigation systems are in the best way coordinated with the lognormal probability distribution law and their statistical parameters depend on the sizes of irrigated area.

2. Most adequate to stochastic nature of water distribution and use is the method of preventive control of water delivery in canal reaches that compensates the perturbances in diversion capacity by consumers.

3 . The optimum irrigation area from one delivery points, at which the perturbances in diversion capacity is minimal, is about $2-3$ thousand ha. 
4. The quality characteristic of water distribution and use under irrigation is the minimal value of water removal, which all other conditions being equal amounts due to water accumulation in canal beds and special resources.

\section{REFERENCES}

1. SvanidZE G.G., 1964. Calculation basis of water flow management by Monte-Carlo method: 272.

\section{STRESZCZENIE}

\section{Kontrola systemu nawadniania w warunkach niepewności}

Słowa kluczowe: nawodnienia, rozrzqd $i$ kontrola zużycia wody

Kontrola systemu nawadniania jest uważana za złożony proces hierarchiczny o charakterze stochastycznym, u podstaw którego leży niepewność spowodowana losowymi zmianami czynników meteorologicznych (klimatycznych) i reżimem możliwości zawracania wody z kanałów irygacyjnych.

W tych warunkach użycie określonych sposobów kontroli systemu nawadniania w kontekście jego wydajności można sprawdzać metodami formalistycznymi i empirycznymi. Najbardziej odpowiednia jest zaproponowana przez nas metoda kontroli prewencyjnej.

W wyniku analizy retrospektywnej każdemu stanowi systemu (np. zdolności zawracania wody) przypisano czynnik, który powoduje jego zmianę (np. wielkość opadów lub parowanie). Każdej sekwencji „,czynnik-stan systemu” przypisano wskaźnik, który określa prawdopodobieństwo jego przekroczenia w retrospektywnej serii.

Kontrola polega na śledzeniu dynamiki tych wskaźników, na przewidywaniu najbardziej prawdopodobnych zmian stanu systemu i dostosowaniu reżimu dostawy wody do reżimu zawracania wody $\mathrm{z}$ kanałów irygacyjnych $\mathrm{z}$ zastosowaniem standardowych prewencyjnych wykresów przepływu wody przez struktury hydrauliczne i stacje pomp.

Użycie takich metod kontroli pozwala zminimalizować wpływ niepewności i nie wymaga znacznych modyfikacji projektowania czy infrastruktury inżynieryjnej.

Wyjątkiem mogą być środki, zmierzające do zwiększenia samoregulacyjnych zdolności systemu nawadniania, zwłaszcza możliwości bieżącej kontroli martwej objętości wody w korytach kanałów lub specjalnych zbiornikach.

Przykładem podejmowania takich decyzji w praktyce jest system irygacyjny Kakhovskaya na południu Ukrainy. W niekorzystnych warunkach pogodowych 
współczynnik zużycia wody w tym systemie siega 0,85 , odpływ wody technologicznej nie przekracza 7\%, deficyt zasobów wilgoci w glebie pod koniec okresu między nawodnieniami nie przekracza $20 \%$.

Received 26.11.2007

Reviewers:

Dr Antoni Kuźniar

Prof. Leszek Łabędzki 